\title{
Detection of Antimony in Drinking Water Bottles Produced in Iraq
}

\author{
Farqad Abdulla Rashid*, Hiyam Isam Shakir and Maha Salah Nawar
}

Key Laboratory of Food Research Center of Ministry of Science and Technology, Directorate of Environment and Water, Baghdad 10001, Iraq

*Corresponding author

\section{A B S T R A C T}

\begin{tabular}{|l|}
\hline K e y w o r d s \\
Antimony, PET \\
Bottles, Atomic \\
Absorption, \\
Temperature, \\
Duration
\end{tabular}

\section{Introduction}

Even though Iraq has major rivers as herbal water sources, these resources are typically polluted, biologically and chemically due to lack in suitable systems for secure disposal of sewage, wastewater, commercial, agricultural and medical waste. Water treatment plants, pumping stations and water networks suffered from lack of upkeep result breakdown. (Stars Orbit Consultants and Management Development, 2010) in standard, the best of water is equally crucial as its amount consequently; water exceptional is considered as the issue to decide surroundings adjustments which can be strongly associated with social and monetary improvement. (1) Bottled water can be defined as any potable water that is synthetic, disbursed or presented for sale, sealed in food-grade bottles or other sanitary container and intended for human consumption assets of water in bottled water may be springs, wells, or other approved assets, the water inner these bottles may be distilled, carbonated, ozonized or filtered (1, 2).

In developing nations approximately 1.8 people, frequently kids, die each year due to water associated illnesses. tap water can be harmful to human health because of infection with microbes. Tap water high-quality may 
additionally trade due to exposure to the encompassing surroundings as open tanks or in pipes all through distances before attaining the clients, (3) the most important function of bottled water over tap water is the excellent, specifically in terms of flavor and regularity. consequently, bottled drinking water is one of the most critical assets of drinking water now not most effective in Iraq, but also within the whole global (World Health Organization (WHO), 2004) bottled water industry is one of the most thriving industries, in Iraq and global. it's miles the quickest developing drink choice where water consumption global is expanded via common $10 \%$ yearly, consequently, became the most dynamic quarter of all meals and beverage industries due to accessibility, pretty low value, better taste, and lower stage of impurities. The plastic material for packaging ingesting water differ from country to us of a, however the commonplace bundle material used is polyethylene terephthalate (PET) (4) this is because of its great fabric properties like unbreakability, exact barrier properties toward moisture, high readability, low migration trends for residual constituents and very low weight of the bottles as compared with glass bottles of the equal filling capability (5) it's far crafted from the polymerization of petroleum monomers of terephthalic acid and ethylene glycol using antimony-, titanium-, or germanium-based totally catalysts (5) over ninety percent of globally synthetic pet make use of antimony-based totally catalysts, predominantly antimony trioxide (Sb2O3) with useful characteristics like excessive catalytic interest, low tendency to catalyse aspect reactions, creates no coloration in the final product and has low-value rate (5) an expected 150 billion plastic bottles are created from puppy resins yearly (6) commercialised pet resins made from using sb2o3 catalysts typically have residual sb ranging among 150$300 \mathrm{mg} / \mathrm{kg} \quad(4,7)$ these residual antimony amounts are very high and raise concerns, thinking about earlier findings that, antimony was found to migrate into water and beverages stored in PET plastic packing containers over time. (4) $\mathrm{Sb}$ itself is a regulated consuming water contaminant and a non-critical detail for flora and animals and has no acknowledged organic or physiological characteristic and on a long-term exposure has been suspected to be carcinogenic $(4,5,6)$ in cases of acute intoxication, signs and symptoms such stomach and muscle aches, diarrhoea, desiccation, shocks, anaemia and uraemia may rise up. Those cause extreme myocardial inflammation, shivering, necrosis and in the end loss of life (4) other adverse ailments related to long-time period publicity to this metalloid include pneumonitis, fibrosis, bone marrow harm and carcinomas (8). numerous environmental elements have been located to affect the migration of antimony from the plastic container into the water stored internal. effects of things like temperature, daylight, period and physicochemical residences among others on migration were studied in other parts of the world $(4,5,6,7)$.

Climatic situations in our part of the arena are very one-of-a-kind and greater intense with variations in seasons. Furthermore, the source of water for bottling and the packing fabric differs from one production agency to another. As a result, it's far imperative that puppy bottled water saved below triumphing conditions be studied to envision whether migration quotes are excessive main to infection.

\section{Materials and Methods}

\section{Sampling}

We collected drinking bottles water from Jan to March 2018 that produced locally in 7 different factories located in 7 provinces that covers Baghdad, middle Euphrates provinces and south provinces (Table 1), from each 
factories we collected 20 different batch bottles.

\section{Chemicals and regents}

All solutions were prepared using ultrapure water. Nitric and hydrochloric acids (Merck, Darmstadt, Germany) used were of analytical grade. The antimony standard solutions were obtained by diluting a stock solution $1000 \mathrm{mg}$ L-1 Merck Darmstadt, Germany). Working solutions were prepared by appropriate dilution of a middle solution of $10 \mathrm{mg} \mathrm{L}-1$. Glassware used was heated at $450{ }^{\circ} \mathrm{C}$ for at least $4 \mathrm{~h}$ to prevent cross contamination.

\section{Sb concentration in PET bottles}

The bottles were digested to determine total $\mathrm{Sb}$ in PET plastic according to Hureiki and Mouneimne (7) and Westerhoffet (5).The bottles were cut into $4 \times 4 \mathrm{~mm}^{2}$ pieces. $0.5 \mathrm{~g}$ of plastic samples were mixed with $8 \mathrm{ml} \mathrm{HNO}_{3}$ and $2 \mathrm{ml} \mathrm{H}_{2} \mathrm{O}_{2}$, and digested on a Hotplate for $1 \mathrm{~h}$ at $125^{\circ} \mathrm{C}$. Sb in bottle was completely dissolved since only white powder residue remained in the digested solution. The digested solutions were diluted with deionized water, filtered through a $0.45 \mu \mathrm{m}$ PES filter, and determined for $\mathrm{Sb}$ by Atomic Absorption Spectrophotometer (HVG.A.A.S),(SHIMADZU-7000).

\section{Release of Sb from PET bottles}

Effects of storage temperature on $\mathrm{Sb}$ release from bottles was investigated at 25, 40,60 and $-4^{\circ} \mathrm{C}$, simulating three storage conditions, ie.. Storage in refrigerator, room temperature, and high temperature. Bottles were stored for 7 and $14 \mathrm{~d}$ at $25,40,60$, and $-4^{\circ} \mathrm{C}$, respectively. After 7 and $14 \mathrm{~d}$, water in bottles was sampled to determine $\mathrm{Sb}$. Deionized water was emptied from the bottles after 1 week of storage, and analyzed for $\mathrm{Sb}$ concentrations. Fresh deionized water was added again to those bottles and stored for another week. The released concentration of $\mathrm{Sb}$ after 2 week of storage was accumulative of two weeks.

The concentration of $\mathrm{Sb}$ in water was determined by hydride vapor generator H.V.G.. To measure the fluorescence intensity of the antimony, an atomic spectrometer with hydrides generator, HG-AFS (Model SHIMADZU-7000) was used with a coupled quartz gas-liquid separator. Argon) was used as carrier gas and the flame was maintained by the $\mathrm{C} 2 \mathrm{H} 2$ generated parallel to the hydride reaction of $\mathrm{HCl}$ with $\mathrm{NaBH} 4$ A high intensity hollow cathode lamp (SHIMADZU) was used as excitation source of the analyte.

\section{Results and Discussion}

\section{Total Sb in PET bottles}

Total concentration of $\mathrm{Sb}$ (by H.V.G after HNO3-digestion) in bottles is listed in Table 1. The $\mathrm{Sb}$ concentrations ranged from 21.436 to $213.740 \mu \mathrm{g} / \mathrm{g}$, which were similar those in previous studies $(4,9)$. For example, $\mathrm{Sb}$ concentrations in PET bottles from Hungarian, Nigeria, and Britain were 210-290 (4), 178287 , and $195-242 \mathrm{mg} / \mathrm{kg}$ (9), indicating variable quality of plastics in different countries. The total $\mathrm{Sb}$ released from bottle can be seen in tables, which is higher than the MCL of $5 \mu \mathrm{g} / \mathrm{L}$ of $\mathrm{Sb}$ in Iraq (Ministry of Health, 2006).

Clearly, it is unlikely that all $\mathrm{Sb}$ in bottles will be released into water. Therefore, releasing tests under various storage conditions are necessary to better understand release behaviors of $\mathrm{Sb}$ from bottles.

\section{Relationship of variable temperature and duration on $\mathrm{Sb}$ release from bottles}

Effect of storage temperature on $\mathrm{Sb}$ release from bottles was investigated by storing 
bottles at $-4,25,40$ and $60{ }^{\circ} \mathrm{C}$ for $7 \mathrm{~d}$ and 14 d. $\mathrm{Sb}$ concentration ranged from (Nil) $\mu \mathrm{g} / \mathrm{L}$ at $-4{ }^{\circ} \mathrm{C}$. Temperature increase to $25{ }^{\circ} \mathrm{C}$ enhanced $\mathrm{Sb}$ release from bottle, which ranged from (0.931) to (7.364) $\mu \mathrm{g} / \mathrm{L}$ with the median at (3.218) $\mu \mathrm{g} / \mathrm{L}$. When comparison was based on single type, $\mathrm{Sb}$ release increased by (7) times if temperature increased to $25^{\circ} \mathrm{C}$, which is consistent with Reimann et al., (2012) 10. For instance, for European PET bottles, 2.76$23.3 \mathrm{ng} / \mathrm{L} \mathrm{Sb}$ was released after stored at $2^{\circ} \mathrm{C}$ for $7 \mathrm{~d}$, and 11.7-54.1 ng/L Sb was released at $25{ }^{\circ} \mathrm{C}$ (Reimann et al., 2012) 10. However, much higher $\mathrm{Sb}$ concentration (8.90-2570 ng/L) was reported by Shotyk and Krachler (2007) 6 based on 69 brands of PET bottles, which were stored at room temperature for 6 months. Higher Sb levels reported by (6) can be attributed to longer storage time (six months) compared with the current study and (10)(1 week). Even though higher median concentration $(1.301--8.246 \mu \mathrm{g} / \mathrm{L})$ of $\mathrm{Sb}$ in the bottled was measured at $40^{\circ} \mathrm{C}$ than those at $25^{\circ} \mathrm{C}(0.931--7.364 \mu / \mathrm{L})$. When stored at $60^{\circ} \mathrm{C}$, substantially higher $\mathrm{Sb}$ was observed across all bottles ranging from 2.034--11.015 $\mu / \mathrm{L}$. When compared among the three temperatures, $\mathrm{Sb}$ concentrations increased by 2 - 11 times when temperature increased from -4 to $60{ }^{\circ} \mathrm{C}$, and 2 times when temperature increased from 25 to $60{ }^{\circ} \mathrm{C}$ Consistent with our study, a slight increase in Sb concentration in bottled water was reported when storage temperature increased from $2{ }^{\circ} \mathrm{C}$ to $22{ }^{\circ} \mathrm{C}$ (2.76 to $11.7 \mathrm{ng} / \mathrm{L})$, and much higher $\mathrm{Sb}$ (1240 ng/L) was observed when temperature increased to $45^{\circ} \mathrm{C}$ by (10).

When considering $\mathrm{Sb}$ release into water less than $60^{\circ} \mathrm{C}$, the highest $\mathrm{Sb}$ at $11.015 \mu \mathrm{g} / \mathrm{L}$ in the first week was observed for PC plastic and at $28.116 \mu \mathrm{g} / \mathrm{L}$ in the second week. Since $\mathrm{Sb}$ release was mainly controlled by degradation of plastics (11), it was expected that PC was easier to be degraded under high temperature. The relatively low $\mathrm{Sb}$ release observed for other plastic is comparable with the result of (12) who reported that $\mathrm{Sb}$ concentrations in most PET bottles were $<1 \mathrm{mg} / \mathrm{L}$ after $70 \mathrm{~d}$ storage at 60 C. Nevertheless, higher concentrations were reported in other studies. For example, $\mathrm{Sb}$ concentrations ranged from 3.5 to $10.9 \mathrm{mg} / \mathrm{L}$ after storing PET bottles at $6080 \mathrm{C}$ for 1 week $(5,8,10)$. The variable $\mathrm{Sb}$ release levels among different studies can be attributed to different quality of plastics materials, which may vary depending on raw materials as well as technology used for plastic production Although Sb release levels varied with different studies, the fact that elevated temperatures (e.g., $60{ }^{\circ} \mathrm{C}$ ) significantly increased $\mathrm{Sb}$ release into water was confirmed.

To evaluate the effect of storage duration on $\mathrm{Sb}$ release, $\mathrm{Sb}$ concentration released from bottles were measured after 1, 2, week storage at $60{ }^{\circ} \mathrm{C}$. Our data showed that $\mathrm{Sb}$ concentrations increased significantly with storage duration for 3 of 7 brand PET bottles.

Sb releasing rate was calculated (Equation 2) and decreased with storage duration for all brands (Table 2). It is expected that limited Sb was released from PET bottles over long storage duration as $\mathrm{Sb}$ release rate may gradually decreased to zero. This is consistent with (13) who showed that Sb concentration increase with storage duration gradually decreases under different temperatures.. Therefore, longer storage duration should be employed to reach the maximum release concentration of $\mathrm{Sb}$ in PET bottled water.

Our study shows that concentration of $\mathrm{Sb}$ increased with duration of 14 days for all types of bottles especially type 3 and type 7 (Table 3). Sb release from 7 brands of drinking water bottles in Iraq was investigated by storing bottles under different temperature and durations. Release of $\mathrm{Sb}$ increased with storage temperature, especially at $60{ }^{\circ} \mathrm{C}$, 
hence storing bottles under high temperature is similar to what happened in local warehouse of drinking water bottles especially. Meanwhile, more attention should be given to other drinks packaged using PET plastic, such as milk, coffee, and acidic juice, and other types of food containers. This is because the ingredient of these drinks and food are more complex compared to drinking water, thus may induce more contaminants release and also more complicated speciation from the containers. For example, $\mathrm{Sb}$ concentrations in commercial juices are detected up to 2.7-fold above the EU limit for drinking water $(5 \mathrm{mg} / \mathrm{L})$. The more toxic inorganic $\mathrm{Sb}$ (III) (44\%) and an $\mathrm{Sb}(\mathrm{V})$ ecitrate complex with un- known toxicity $(41 \%)$ are the main species in the juices

Table.1 Concentration of $\mathrm{Sb}$ in plastic

\begin{tabular}{|c|c|c|}
\hline Plastic symbol no. & Local Market Brand Name & $\mathrm{Sb}(\mu \mathrm{g} / \mathrm{g})$ \\
\hline $\mathbf{1}$ & Kut & 21.436 \\
\hline $\mathbf{2}$ & Thi-Qar & 162.770 \\
\hline $\mathbf{3}$ & Basrah & 153.129 \\
\hline $\mathbf{4}$ & Karbala & 150.231 \\
\hline $\mathbf{5}$ & Maysan & 31.263 \\
\hline $\mathbf{6}$ & Baghdad & 52.460 \\
\hline $\mathbf{7}$ & Mousl & 213.740 \\
\hline
\end{tabular}

Table.2 Concentration of $\mathrm{Sb}$ in water in the first week $(\mu \mathrm{g} / \mathrm{l})$

\begin{tabular}{|c|c|c|c|c|}
\hline & at $25^{\circ} \mathrm{C}$ & at $40^{\circ} \mathrm{C}$ & at $60^{\circ} \mathrm{C}$ & at $-4{ }^{\circ} \mathrm{C}$ \\
\hline $\mathbf{1}$ & 0.931 & 1.301 & 2.034 & $\mathrm{Nil}$ \\
\hline $\mathbf{2}$ & 3.036 & 5.301 & 8.962 & $\mathrm{Nil}$ \\
\hline $\mathbf{3}$ & 6.654 & 7.972 & 10.024 & $\mathrm{Nil}$ \\
\hline $\mathbf{4}$ & 2.379 & 2.378 & 3.635 & $\mathrm{Nil}$ \\
\hline $\mathbf{5}$ & 1.648 & 2.067 & 2.670 & $\mathrm{Nil}$ \\
\hline $\mathbf{6}$ & 1.961 & 2.668 & 3.048 & $\mathrm{Nil}$ \\
\hline $\mathbf{7}$ & 7.364 & 8.246 & 11.015 & $\mathrm{Nil}$ \\
\hline
\end{tabular}

Table.3 Concentration of $\mathrm{Sb}$ in water in the second week $(\mu \mathrm{g} / \mathrm{l})$

\begin{tabular}{|l|l|l|l|l|}
\hline & at $25^{\circ} \mathrm{C}$ & at $40{ }^{\circ} \mathrm{C}$ & at $60{ }^{\circ} \mathrm{C}$ & at $-4{ }^{\circ} \mathrm{C}$ \\
\hline $\mathbf{1}$ & 7.092 & 8.302 & 10.239 & Nill \\
\hline $\mathbf{2}$ & 20.039 & 20.304 & 23.934 & Nill \\
\hline $\mathbf{3}$ & 16.774 & 16.88 & 19.023 & Nill \\
\hline $\mathbf{4}$ & 7.589 & 8.389 & 9.093 & Nill \\
\hline $\mathbf{5}$ & 9.659 & 9.991 & 12.234 & Nill \\
\hline $\mathbf{6}$ & 8.981 & 8.092 & 9.237 & Nill \\
\hline $\mathbf{7}$ & 24.370 & 28.338 & 28.116 & Nill \\
\hline
\end{tabular}


Our study shows that concentration of $\mathrm{Sb}$ increased with duration of 14 days for all types of bottles especially type 3 and type 7 (Table 3). Sb release from 7 brands of drinking water bottles in Iraq was investigated by storing bottles under different temperature and durations. Release of $\mathrm{Sb}$ increased with storage temperature, especially at $60{ }^{\circ} \mathrm{C}$, hence storing bottles under high temperature is similar to what happened in local warehouse of drinking water bottles especially. Meanwhile, more attention should be given to other drinks packaged using PET plastic, such as milk, coffee, and acidic juice, and other types of food containers. This is because the ingredient of these drinks and food are more complex compared to drinking water, thus may induce more contaminants release and also more complicated speciation from the containers. For example, $\mathrm{Sb}$ concentrations in commercial juices are detected up to 2.7-fold above the EU limit for drinking water $(5 \mathrm{mg} / \mathrm{L})$. The more toxic inorganic $\mathrm{Sb}$ (III) (44\%) and an $\mathrm{Sb}(\mathrm{V})$ ecitrate complex with un- known toxicity $(41 \%)$ are the main species in the juices.

\section{Author contributions}

Farqad Abdulla Rashid designed the experimental scheme and did the most of the sample preparation and characterizations. Hiyam Isam Shakir analyzed the experimental data. Farqad Abdulla Rashid and Maha Salah Nawar wrote and revised the manuscript. Maha Salah Nawar and Hiyam Isam Shakir helped with the experiment. All authors reviewed the manuscript.

\section{Acknowledgment}

This work was financially supported by the Ministry of Science and Technology, Directorate of Environment and Water, Food Research Center.

\section{References}

1. Toma, J., Ahmed, R. Application of water quality index for assessment water quality in some bottled water Erbil City, Kurdistan Region, Iraq. Journal of Advanced Laboratory Research in Biology 2013. 4(4), 118124.

2. Alabdula'aly, and Khan, Abdulrahman, I. and Mujahid A Khan Chemical Composition of Bottled Water in Saudi Arabia Environmental Monitoring and Assessment. 1999. 54(2):173-189 .

3. Fasano, E.; Bono-Blay, F.; Cirillo, T.; Montuori, P.; Lacorte, S. Migration of phthalates, alkylphenols, bisphenol A and $\operatorname{di}(2$-ethylhexyl)adipate from food packaging. Food Control 2012, 27, 132-138.

4. Keresztes, S., Tata,r, E., Mihucz, V.G., Vira, G, I., Majdik, C., Zaray, G., Leaching of antimony from polyethylene terephthalate (PET) bottles into mineral water. Sci. Total Environ. 2009. 407, 4731-4735.

5. Westerhoff, P., Prapaipong, P., Shock, E., Hillaireau, A. Antimony leaching from polyethylene terephthalate (PET) plastic used for bottled drinking water. Water Res. 2008. 42, 551-556

6. Shotyk, W., Krachler, M. Contamination of bottled waters with antimony leaching from polyethylene terephthalate (PET) increases upon storage. Environ. Sci. Technol. 2007. 41, 1560-1563

7. Hureiki, L., Mouneimne, Y. Antimony release in PET bottled natural water in Lebanon. Water Sci. Technol. Water Supply 2012. 12, 193-199.

8. Bach C., Dauchy, X., Severin, I., Munoz, J.F., Etienne, S., Chagnon, M.C. Effect of temperature on the release of intentionally and non- 
intentionally added sub- stances from polyethylene terephthalate (PET) bottles into water: chemical analysis and potential toxicity. Food Chem. 2013. 139, 672-680

9. Tukur, A., Sharp, L., Stern, B., Tizaoui, C., Benkreira, H. PET bottle use patterns and antimony migration into bottled water and soft drinks: the case of British and Nigerian bottles. J. Environ. Monit. 2012. 14, 1236-1246.

10. Reimann, C., Birke, M., Filzmoser, P. Temperature-dependent leaching of chemical elements from mineral water bottle materials. Appl. Geochem. 2012. 27, 1492-1498

11. Takahashi, Y., Sakuma, K., Takaakiitai, Zheng, G.D., Mitsunobu, S. Specification of antimony in PET bottles from Japan and China by X-ray absorption fine structure spectrometry. Environ. Sci. Technol. 2008. 42, 9045-9050.

12. Greifenstein, M., White, D.W., Stubner, A., Hout, J., Whelton, A.J. Impact of temperature and storage duration on the chemical and odor quality of military packaged water in polyethylene terephthalate bottles. Sci. Total Environ. 2013. 456-457, 376383.

13. Rungchang, S., Numthuam, S., Qiu, X.l., Li, Y.J., Satake, T. Diffusion coefficient of antimony leaching from polyethylene terephthalate bottles into beverages. J. Food Eng. 2013. 115, 322.

\section{How to cite this article:}

Farqad Abdulla Rashid, Hiyam Isam Shakir and Maha Salah Nawar. 2018. Detection of Antimony in Drinking Water Bottles Produced in Iraq. Int.J.Curr.Microbiol.App.Sci. 7(12): 2644-2650. doi: https://doi.org/10.20546/ijcmas.2018.712.300 